DOI 10.32726/2411-3417-2019-4-33-44

УДК 94; 327

\title{
Сepreй ЗОтов
}

\section{Как России после вывода войск из Латвии удалось сохранить на 6 лет станцию предупреждения о ракетном нападении в Скрунде. Воспоминания российского посла}

Аннотация. После получения Латвией независимости в 1991 2. встал вопрос о выводе советских войск и военных объектов с территории республики. Добиться приемлемых для России условий вывода в обстановке эйфории «нового мышления» и яростной кампании латвийских национал-радикалов было не просто трудно, но казалось невозможным. Автор статьи, возглавлявший государственную делегацию РФ на переговорах с Латвией по этим проблемам, раскрывает малоизвестную историю развернувшейся дипломатической борьбы, анализирует ее внутренний и международный контекст, ее значение для России, ход, обстоятельства и уроки.

Ключевые слова: российская дипломатия, переговоры между Россией и Латвийской Республикой, вывод войск из Латвии, РЛС в Скрунде, система предупреждения о ракетном нападении, «пакетное решение».

31 августа 2019 г. исполнилось 25 лет с того дня, когда в 1994 г. территорию Латвии покинула 25-я бригада Северо-Западной группы войск - последняя воинская часть Вооруженных сил России, в составе 58 тыс. военнослужащих, остававшихся в Латвии после распада СССР. На латвийской территории находились еще три военных объекта, имевших стратегическое значение для России: радиолокационная станция (РЛС) системы предупреждения о ракетном нападении (СПРН) в Скрунде, центр слежения за космическими объектами в Вентспилсе и база подводных лодок Балтийского флота в Лиепае.

После получения Латвией из рук России независимости встал вопрос о выводе с территории Латвии вооруженных сил бывшего СССР, получивших статус «иностранных» войск, находящихся под юрисдикцией Российской Федерации.

Добиться приемлемых для России условий вывода войск в обстановке эйфории «нового мышления» было не просто трудно, но казалось невозможным. Против нас было практически все - и яростная кампания национал-радикалов в самой Латвии, и не

Сведения об авторе: ЗОТОВ Сергей Сергеевич - российский дипломат, чрезвычайный и полномочный посол, в 1992-1996 г2. - посол по особым поручениям МИД России, руководитель государственной делегации Российской Федерачии на переговорах с Латвийской Республикой о выводе войск. 
менее агрессивная кампания против всего советского наследия в самой России, где российские идеологические гуру 90-х годов в своих оценках не менее рьяно трактовали советскую историю прибалтийских республик как «оккупацию», называя русских «оккупантами», а армию - «оккупационной». Россия, бывшая в начале 1990-х годов в состоянии мировоззренческого паралича, не смогла дать адекватный отпор постепенному внедрению в политическое сознание концепции «воссоздания довоенных государств», хотя акты признания Советским Союзом независимости Прибалтики не содержат такого юридического тезиса, а лишь дают ссылку на «конкретную историческую и политическую обстановку, предшествовавшую вхождению Латвийской Республики в СССР» [Постановление...].

В этой атмосфере указом президента РФ была образована государственная делегация во главе с послом по особым поручениям С.С. Зотовым, получившим статус полномочного представителя президента [Указ...]. Главе делегации были даны широкие полномочия для ведения сложнейших переговоров, призванных обеспечить цивилизованный «развод» двух республик, проживших полвека под одной крышей, и подвести под этот «бракоразводный» процесс солидную договорно-правовую базу. Особую трудность представляли военные вопросы. Предписывалось сделать все возможное для решения комплекса таких задач, как:

- выработка достойных для России условий планомерного вывода войск в приемлемые сроки и их правового положения на период вывода;

- обеспечение прав российских граждан, в том числе военных пенсионеров и этнических россиян, проживающих в Латвии;

- достижение договоренностей о продолжении функционирования на временной основе после вывода войск трех стратегических объектов РФ;

- решение вопросов компенсации за оставляемое войсками движимое и недвижимое имущество ВС РФ.

Латвийская сторона изначально рассчитывала на поддержку Запада и идейную обстановку в самой России, где явные проприбалтийские симпатии гнездились, в том числе, в руководстве МИД РФ, в окружении министра иностранных дел А. Козырева. Поэтому в начале переговоров она фактически выдвигала ультиматумы в ответ на четко поставленные российской делегацией практические вопросы. То, что в конечном итоге, наряду с достойными условиями вывода российских войск, удалось одновременно добиться решения вопросов социальной защищенности военных пенсионеров, военнослужащих и их семей, проживавших на территории Латвии, и договориться о правовом статусе РЛС в Скрунде - результат исключительного упорства и твердости российской делегации. Ей, состоявшей из высокопрофессиональных дипломатов и переговорщиков классической советской школы, а не «революционного призыва», приходилось и завышать изначальную планку, и принимать решения на свой страх и риск, и смело обращаться напрямую к президенту РФ, когда козыревское руководство МИД готово было во всем потакать другой стороне.

С самого начала переговоров латвийская делегация резко негативно отреагировала на постановку нами вопроса о продолжении функционирования стратегических объек- 
тов ВС РФ. Было заявлено, что латвийская сторона не допустит военных баз на своей территории. Вывод войск должен был, по ее мнению, быть «полным и безоговорочным».

Добиться сдвига в этом вопросе после двухлетних баталий удалось только путем жесткой увязки в единый пакет вопроса сокращения сроков вывода войск, что имело капитальное значение для латышей, с достижением соглашений по вопросам социальной защиты военных пенсионеров и сохранения РЛС в Скрунде после вывода войск. После объявленного президентом РФ сокращения срока вывода войск на 5 лет (он был перенесен с 1999 г. на 1994 г.) Латвия добивалась завершения этого вывода к сентябрю 1994 г.

Идея «пакетного решения», часто применяемого в дипломатических переговорах, вызвала противодействие не только латвийской делегации, но и окружения министра А.В. Козырева. В последующем с обеих сторон долгое время предпринимались попытки разорвать этот «пакет». Они напоминали детектив: тайные поездки козыревских посланцев в Ригу за спиной госделегации, утечки информации на Смоленской площади, дезавуирование заявлений главы госделегации, подсовывание президенту РФ натовской идеи приоритетного и досрочного вывода только боевых частей, подмена концепции подписания межгосударственных документов суррогатным и ни к чему не обязывающим латвийскую сторону «меморандумом». Это была предательская линия А.В. Козырева с единственной целью - выполнить требование покровительствовавших ему Соединенных Штатов и «закрыть» РЛС в Скрунде.

Твердость госделегации в отстаивании «пакетного» подхода дала свои результаты. В январе 1994 г. латвийская сторона вынуждена была начать обсуждение судьбы стратегических объектов ВС РФ на период после вывода войск. Мы добивались, чтобы для РЛС системы предупреждения о ракетном нападении был установлен срок временного функционирования в 10 лет, для Центра в Вентспилсе - 6 лет, для базы подводных лодок Балтийского флота в Лиепае - 5 лет. Переговоры шли трудно. Мы вынуждены были отказаться от объектов в Вентспилсе и Лиепае, чтобы сохранить РЛС СПРН в Скрунде.

О геостратегической важности для России этого объекта мне рассказали в Кремле руководители Совета Безопасности РФ. Такие станции - технически сложные и дорогостоящие объекты (0,5 млрд. руб. в ценах 1991 г.) - были уже развернуты или находились в стадии завершения развертывания по периферии бывшего СССР и создавали сплошное радиолокационное поле слежения за воздушно-космическим пространством. В считаные секунды станция системы предупреждения о ракетном нападении фиксировала запуск ракеты в любой точке земного шара, показывала ее траекторию и поражаемую цель, выдавала координаты как для ракеты-перехватчика, так и для всей отечественной глобальной системы ПРО, включая подводные лодки в Мировом океане и космические средства. Была создана единая цепь из 9 РЛС СПРН по периметру территории СССР. После распада единой страны на территории нынешней РФ находились 3 станции, а еще 6 на тот период оказались на территориях стран СНГ - 
Азербайджана, Беларуси, Казахстана, Украины - и Латвии. В связи с образованием суверенных государств встал вопрос об определении статуса и порядка использования станций СПРН, оказавшихся за пределами России. Переговоры с этими государствами проходили в непростой обстановке, но Россия надеялась на позитивный исход и заключение соответствующих соглашений.

Нелишне привести весьма меткие суждения Н.А Нарочницкой о том, как можно было бы использовать один трудно оспариваемый аргумент, сформулированный в ряде ее работ и выступлений: важной особенностью военно-стратегического положения России после разрушения СССР было то, что новые границы РФ не совпадали с ее военно-стратегическим пространством, коим по-прежнему оставалась территория СССР. Этот тезис юридически следовал из того, что Россия была признана всем миром и прежде всего Соединенными Штатами (тогда остро заинтересованными в нерасползании ответственности в области ядерных вооружений) как единственный «продолжатель личности» (континуитет) СССР во всех договорах по ядерному разоружению. Этот факт никем никогда не оспаривался, однако юридические следствия такого положения почему-то не использовались российской внешней политикой 1990-х годов.

Полезно было осознавать, пишет Н.А. Нарочницкая, что существует понятие «географическая зона действия договора». Именно территория СССР в конкретных военно-стратегических характеристиках, измерениях и конфигурациях определена как то географическое пространство, на котором продолжили и в послесоветское время действовать все договоры по разоружению, включая фундамент этой договорной системы - Договор об ограничении систем противоракетной обороны (Договор по ПРО, 1972) и Протокол к нему (1974), Временное соглашение о некоторых мерах в области стратегических наступательных вооружений (ОСВ-І, 1972), Договор об ограничении стратегических наступательных вооружений (ОСВ-ІІ, 1979), Договор о ликвидации ракет средней и меньшей дальности (РСМД, 1987), Договор о сокращении обычных вооружений в Европе (ДОВСЕ, 1990) и Договор о сокращении и ограничении стратегических наступательных вооружений (CHB-I, 1991).

Следовательно, логично рассуждает Н.А. Нарочницкая [Нарочницкая, с. 492-493], Российская Федерация унаследовала военно-стратегическое пространство Советского Союза в качестве зоны своей договорной ответственности и ядерной безопасности. Ни одно государство не может допустить появления на своем военно-стратегическом пространстве вооруженных сил третьих государств или вступления частей этого пространства в союзы и блоки, направленные против него. Этот тезис мог бы быть своевременно сделан юридическим инструментом обоснования красной линии нераспространения НАТО. Однако Москвой он не был использован в обстановке полной идеологической и морально-политической разоруженности перед США [Там же].

Помимо этого в статье VI (пункт b) Договора об ограничении систем ПРО содержится обязательство «не развертывать в будущем РЛС предупреждения о нападении стратегических баллистических ракет, кроме как на позициях по периферии своей национальной территории с ориентацией вовне» [Договор...26 мая 1972]. Таким ограниче- 
нием Договор запрещал одновременное функционирование станций и как «системы предупреждения», и как «РЛС системы ПРО». А это означало, что демонтировать станцию в Скрунде и перенести в глубь географической зоны действия Договора ПРО - то есть уже на территорию РФ - не только было бы технически невозможно, но и стало бы нарушением статьи VI Договора по ПРО. С течением времени такой аргумент постепенно терял действенность, ибо США тяготились Договором по ПРО и, как известно, отказались от него в 2002 г.

Тем не менее руководители Совета безопасности РФ подчеркивали особую важность сохранения в единой цепочке системы предупреждения о ракетном нападении узла в Скрунде, расположенного на самом опасном для нас участке потенциального ракетного удара. Перед госделегацией на переговорах с Латвией ставилась задача добиться сохранения объекта «любой ценой», хотя бы на минимальный срок в 4 года, который позволял компенсировать потерю созданием дублирующей системы на станции в Барановичах (Белоруссия) и в космосе. Меня информировали о том, что США скрытно всячески противодействуют сохранению РЛС в Скрунде через своих людей в латвийских политических кругах.

Переговоры начались на фоне провокации: «неизвестными» под покровом ночи была взорвана бетонная мачта линии энергоснабжения РЛС, была развернута кампания в СМИ, доказывавшая опасность-де излучений РЛС для жителей близлежащих населенных пунктов.

Кульминационным моментом в переговорах стал своего рода ультиматум, сформулированный латвийской делегацией по условиям сохранения РЛС. Сама процедура объявления этих условий была подготовлена в расчете на то, что они будут для нас неприемлемыми, и соответственно дальнейшее обсуждение станет невозможным. Предвосхищая свою победу, латвийская делегация пригласила большое количество журналистов и корреспондентов западных СМИ.

Основные требования латвийской стороны заключались в следующем:

- Российская сторона отказывается от статуса РЛС как военной базы.

- На объекте запрещается государственная символика: вывешивание российского государственного флага и пр.

- По всему внешнему периметру объекта устанавливается система охраны латвийским персоналом.

- На объекте вводится пропускной режим для всех работников РЛС, причем постоянные и временные пропуска должны выписываться латвийскими властями.

- Все грузы, оборудование и проч., ввозимые на территорию РЛС и вывозимые с нее, будут подвергаться таможенному досмотру.

- Российская сторона представляет сведения об оружии, имеющемся на территории объекта, включая личное стрелковое оружие; номера такого оружия должны передаваться латвийской стороне.

- Российская сторона берет обязательство за свой счет демонтировать недостроенное здание новой РЛС. 
- Латвийская сторона вводит режим контрольных инспекций на территории РЛС, причем российская сторона соглашается, что эти инспекции могут осуществляться без предупреждения в любое время суток.

- Все надписи по внешней стороне объекта разрешаются только на латышском языке.

Латвийская делегация покинула зал переговоров, чтобы могли обсудить между собой этот латвийский «ультиматум», сочиненный, в чем у нас не было сомнений, не без помощи натовцев. Четыре генерала - члены российской делегации - и все военные эксперты высказались против латвийских предложений и предлагали отклонить их без обсуждений. Я же сразу почувствовал, что можно выхолостить эти требования, ибо для латышской стороны важнее была скорее не суть, а видимость удовлетворения их деклараций. Мне и моим аргументам, что эти предложения можно изощренно вывернуть и выйти на компромиссный вариант, даже гражданские коллеги сначала не поверили, что уж говорить о военных, которые были весьма удручены. Брать паузу в переговорах - означало сыграть на руку нашим противникам. Согласовывать мое решение с руководством МИД не было времени, да и, зная готовность Козырева идти на любые уступки ради одобрения со стороны партнеров на Западе, было опасным и непродуктивным.

Понимая драматизм момента для будущей судьбы РЛС и ссылаясь на широкие полномочия, данные мне президентом РФ, я сказал коллегам, что беру на себя личную ответственность и даю согласие на обсуждение. Я был убежден, что кажущиеся, на первый взгляд, унизительными для персонала РЛС условия на самом деле можно так переформулировать и наполнить, что они не помешают нормальному функционированию объекта.

Приняв к сведению слова генералов о том, что они будут вынуждены доложить о своем несогласии министру обороны, я пригласил в зал латвийских партнеров по переговорам и изумил их заявлением о готовности делегации рассмотреть внесенные ими предложения.

Давая согласие на обсуждение латвийских предложений, мы отметили, что конкретные формулировки «нуждаются в доработке». Требования «проведения инспекций в любое время суток» было нами отвергнуто, но одновременно я предложил как бы даже «усилить» саму идею инспекций, которые, в нашем понимании, должны обеспечить прозрачность деятельности персонала станции и убедить латышей в отсутствии у России планов подрыва ее безопасности. Опираясь на свой 20-летний опыт работы по тематике Хельсинкского процесса, начиная с участия в разработке Заключительного акта в 1972-1975 гг., я предложил придать инспекциям международный характер с использованием механизма СБСЕ. Дипломатическая хитрость заключалась в том, что тем самым устранялось участие в инспекциях скандальных латвийских депутатов-националистов, а правило «консенсуса» в СБСЕ давало нам возможность заблокировать какие-либо нежелательные для нас процедуры. 
Для латвийской делегации и журналистов, собравшихся на «похороны» переговоров по РЛС, которые они так предвкушали, российская конструктивная реакция на латвийский ультиматум стала сенсацией. Противники сохранения РЛС потерпели поражение. Однако до завершения выработки окончательного текста соглашения еще предстояла борьба.

Позднее, уже после подписания с Латвией соглашения о Скрундской РЛС, я представил на пленарном заседании представителей стран-участниц Хельсинкского процесса в Вене положение об инспекциях СБСЕ, которое было одобрено и зафиксировано в документах этой организации. Тем самым Латвия, мечтавшая единолично и полновластно хозяйничать на станции в период ее остаточного существования, полностью лишилась этой возможности, Россия получила дополнительные, притом международные гарантии надежного функционирования РЛС, а само соглашение по РЛС - международноправовое измерение.

16 марта 1994 г. «Соглашение между Российской Федерацией и Латвийской Республикой о правовом статусе Скрундской радиолокационной станции на период ее временного функционирования и демонтажа» [Соглашение...] было согласовано и парафировано главами госделегаций. Это открывало дорогу для визита в Москву президента Латвии Г. Улманиса и подписания подготовленных на переговорах наших делегаций межгосударственных документов.

Срок функционирования РЛС после вывода войск был определен в четыре года (с 01.09.1994 по 31.08.1998), срок демонтажа - в два года (с 01.09.1998 по 29.02.2000). За РЛС закреплялся земельный участок в 164,5 га. Численность персонала была ограничена: не более 559 военных специалистов и 199 гражданских служащих. За ними и членами их семей признавалось право собственности на движимое и недвижимое имущество, право распоряжаться этим имуществом. На территории объекта могла работать средняя школа для детей персонала. Контроль за исполнением Соглашения возлагался на инспекции СБСЕ по графику, предполагающему их проведение в количестве не более двух периодических и двух внеочередных. При внеочередных инспекциях латвийская сторона должна была предупреждать руководителя объекта за 48 часов.

В согласованном тексте Соглашения расходы по демонтажу и сносу недостроенного 10-этажного здания по требованию латышей возлагались на российскую сторону. Их объем Министерство обороны РФ определило в несколько миллиардов рублей (в ценах 1994 г.) и значительную сумму в свободно конвертируемой валюте. Эти средства госделегация должна была запросить в российском правительстве.

Для России расходы на демонтаж и разрушение недостроенного объекта были бы значительным бременем в общей сумме больших затрат, связанных с выводом мощной группировки войск, тем более в момент огромных экономических и бюджетных трудностей, переживаемых страной в 1990-х годах. Но этим жестом Латвия планировала также нанести и политическую пощечину — еще одно унижение России, заставив ее саму уничтожать свое достояние, тем самым дополнительно демонстрируя якобы «оккупационный» характер появления этого стратегического объекта. 
Стремление избежать таких политических издержек подтолкнуло меня к поиску возможностей минимизировать наши затраты по этому обязательству. Я пошел на дипломатическую хитрость: посетил премьер-министра В. Биркавса и в «доверительном плане» сообщил ему, что хотя мы не отказываемся от обязательств, но к столь ожидаемому латышами в июне 1994 г. визиту президента США Б. Клинтона мы никак не сможем осуществить эти работы. В личном плане высказал мысль о том, что американцы с удовольствием профинансируют уничтожение одного из символов «советского присутствия». И это сработало.

Далее, вернувшись в Москву, я пригласил на Смоленскую площадь для беседы временного поверенного в делах США Дж. Мандел, которую мы приняли вместе с моим помощником А.А. Андреевым, ныне являющимся главным советником одного из департаментов МИД РФ. Когда мы ввели американскую коллегу в курс дела, наша собеседница горячо поблагодарила за подсказку, позволяющую, по ее словам, сохранить для западного мира значимость первого визита президента США в Латвию. Она спокойно восприняла сумму в 10 млн. долл., названную мне латвийцами в качестве стоимости демонтажа и взрывных работ, и пообещала согласовать этот вопрос с Вашингтоном. Через неделю Дж. Мандел сообщила, что согласие американских властей на выделение указанной суммы получено. Я информировал об этом наших латвийских коллег, которые с большим удовлетворением согласились внести изменения в согласованный проект Соглашения и записать, что «латвийская сторона за свой счет осущестоляет демонтаж недостроенной станции». Так российская дипломатия позволила госбюджету сэкономить несколько десятков миллиардов рублей, не говоря уже об избавлении России от унижения.

Другая интрига заключалась в том, что в парафированном главами госделегаций проекте не был указан размер годовой арендной платы за пользование земельным участком под РЛС. Латвийская сторона настаивала на том, чтобы взять за пример платежи США по аренде военной базы на Филиппинах - 400 млн. долл. Очевидно, что это была «запросная» позиция, которая представлялась нереальной, и наша делегация ее отвергла. На тот момент мы не успели запросить мнение на этот счет правительства РФ, поэтому я предложил «на свой страх и риск» минимально возможную плату за аренду - 2 млн. долл. против их 400 млн!

На всех последующих встречах госделегаций шел жесткий торг по этому вопросу. Латвийская делегация «спустила» цифру сначала до 240 млн. долл., затем до 140 млн. Мною была названа цифра 3 млн. долл. Эти «ножницы» сохранялись до последней встречи госделегаций, проходившей за несколько дней до объявленного на 30 апреля 1994 г. визита в Москву президента Латвии Г. Улманиса. Оставлять несогласованным текст международного договора, который заблаговременно печатается на гербовой бумаге, было рискованно. После ожесточенных дебатов мы сделали уступку и предложили зафиксировать сумму в 4 млн. долл. Это не было принято. В тексте соглашения оставалось «белое пятно».

К этому времени правительство РФ определило «резервную» позицию для госделегации по аренде на уровне 10 млн. долл., но я был убежден, что в этом вопросе надо 
стоять до конца: у России, несшей огромные расходы по передислокации 58-тысячной армии, лишних денег не было. Я понимал, что шансы на успех в преодолении столь большого разрыва - между 140 млн. долл. и 4 млн. долл. - были минимальными, тем более, что решение передавалось на рассмотрение президентов двух стран. Поэтому 29 апреля, накануне приезда в Москву президента Латвии, я сделал запрос на встречу с первым заместителем главы правительства О.Н. Сосковцом, который в отсутствие премьера В.В. Черномырдина должен был подписать соглашение о РЛС в Скрунде. Он был информирован о серьезных расхождениях в позициях двух делегаций по размерам аренды.

Я попросил Олега Николаевича, как и.о. главы правительства, при обсуждении президентами этого вопроса в Кремле «удержать» Б.Н. Ельцина, насколько это возможно, от значительных уступок в этом вопросе. О.Н. Сосковец пообещать ничего не смог. Тогда я решил попробовать в качестве последнего средства найти возможность изложить свою позицию самому президенту РФ перед его встречей с Г. Улманисом. Помощник президента Д.Б. Рюриков, к которому я обратился за помощью, сообщил, что такая встреча возможна лишь на 5-10 минут по ходу движения Б.Н. Ельцина из своего кабинета в Георгиевский зал Кремля, где проходят торжественные церемонии приема глав иностранных государств. Д.Б. Рюриков рассчитал все по минутам, и я «перехватил» Б.Н. Ельцина в указанном мне месте. Хорошо запомнилось, как мы шли по прогибавшемуся под нами дощатому настилу в бывшем зале заседаний ЦК КПСС, который лучшие реставраторы превращали в «тронный» Андреевский зал Кремля.

Поблагодарив Б.Н. Ельцина за доверие, порученную мне ответственную миссию и за «заявления президента РФ», сделанные по ходу переговоров в поддержку позиций госделегации, я заверил его, что подготовленные к подписанию основной договор об условиях вывода войск и три соглашения полностью отвечают российским национальным интересам.

Б.Н. Ельцин сказал, что доволен тем, как вела переговоры его делегация. Его одобрение меня вдохновило и позволило обратиться к нему с просьбой: если президент сочтет возможным пойти навстречу требованиям латвийской стороны, добивающейся фиксации суммы годовой аренды участка под РЛС в 140 млн. долл., то отстаиваемую делегацией сумму в 4 млн. долл. не следует увеличивать более чем на 1 млн. долл. Когда я попросил Б.Н. Ельцина поддержать эту выверенную и хорошо просчитанную позицию, он ответил одним словом: «Учту».

После церемонии встречи двух президентов гости и участники встречи переместились в Екатерининский зал. Открывая официальную часть переговоров, Б.Н. Ельцин заметил, что в соглашении о правовом статусе РЛС в Скрунде не согласована сумма арендных платежей. «Определять ее - не царское дело» - сказал он и, обращаясь к Г. Улманису, предложил, чтобы О.Н. Сосковец и глава государственной делегации посол С.С. Зотов с российской стороны и представители Латвии вышли в соседний зал и срочно решили эту проблему. Президент Латвии поручил эту работу премьер-министру В. Биркавсу и главе латвийской делегации М. Вирсису. 
В узком составе латвийские гости повторили свое требование установить платежи в размере 140 млн. долл. О.Н. Сосковец назвал нашу цифру в 4 млн. долл. С латвийской стороны последовали отчаянные попытки закрепить сумму аренды сначала на цифре 40 млн. долл., затем 14 млн. долл. Возражая, я подчеркнул, что Россия оставляет в Латвии недвижимое имущество на миллиарды рублей. И идя ва-банк, добавил на свой страх и риск: «Через банки и структуры Латвии идет перекачка огромных средств и ресурсов из России. Перед госделегацией пока не ставилась задача дать правительству РФ предложения по перекрытию каналов ограбления нашей страны на прибалтийском направлении, но я обещаю, что после подписания пакета соглашений по выводу войск госделегация вплотную займется этим вопросом».

Эта «угроза», как мне показалось, попала в цель. Премьер-министр В. Биркавс произнес: «Ваше последнее слово, Олег Николаевич?» О.Н. Сосковец встал, протянул руку гостям и произнес: «Пять миллионов долларов». Развязка наступила вовремя: посланцы двух президентов уже не раз заглядывали в дверь с просьбой ускорить решение вопроса.

Когда я возвращался в Екатерининский зал и проходил мимо кресла Б.Н. Ельцина, он остановил меня. Я сообщил: «Аренда за 5 млн. долл. согласована». Его лицо осветила довольная и даже добрая улыбка, которая для меня была своего рода наградой. После нашей утренней встречи у меня было ощущение, что президент не верил в возможность отстоять минимальную арендную плату на пленарных переговорах с Г. Улманисом, поэтому, чтобы не потерять лицо, публично отправил решать этот вопрос О.Н. Сосковца и меня, давая мне шанс рискнуть и решить проблему на уровне исполнителей.

Согласованная сумма аренды - 5 млн. долл. - была тут же внесена «от руки» в подготовленный к подписанию текст.

Успешное подписание столь ожидаемых международных соглашений было отмечено во Владимирском зале небольшим приемом с шампанским, во время которого Б.Н. Ельцин дважды подходил ко мне, душевно благодарил и крепко жал руку. От министра А.В. Козырева госделегация благодарности не услышала, хотя в официальной Записке МИД Президенту РФ успешное завершение переговоров было оценено как «крупный внешнеполитический прорыв».

Это был действительно прорыв, ибо в начале переговоров латвийская сторона и слышать не хотела ни об увязке вывода войск с соглашениями во другим вопросам, ни об обеспечении прав российских военных пенсионеров, рассчитывая на безоговорочное принятие ее ультиматумов. Теперь же был подписан целый пакет документов: базовый Договор об условиях, сроках и порядке вывода с территории Латвийской Республики ВС РФ и их правовом статусе на период вывода; Соглашение по вопросам социальной защищенности военных пенсионеров и членов их семей, проживающих на территории Латвийской Республики; Соглашение по вопросам социальной защищенности военнослужащих ВС РФ и пограничных войск РФ и членов их семей, временно находящихся на территории Латвийской Республики до полного их вывода; Соглашение о правовом статусе Скрундской РЛС на период временного функционирования и демонтажа [Со- 
глашение...]. (См. Дипломатический вестник, № 11-12, июнь 1994 г.). Такой итог совершенно безнадежного, как казалось вначале, дела, продемонстрировал, как важно бороться до конца, отстаивать каждую пядь, каждую «высоту» не только в годы Великой Отечественной войны, но и в битвах дипломатических.

Тем не менее, с высоты сегодняшнего дня и прошедших 25 лет, подтверждается и грустный вывод о том, что отдельные дипломатические успехи не могут иметь стратегического значения, если в целом сама концепция внешней политики не имеет системной целостности, является капитулянтской, как это было во времена А.В. Козырева, не исходит из признания вечных неизменных интересов страны и даже отличается элементарной близорукостью.

В начале постсоветского периода, отмеченного эйфорией инфантильного сахаровско-горбачевского «нового мышления», различные мозговые центры типа фонда Карнеги распространяли успокоительные идеи, что будто бы постепенно интересы русского населения стран Прибалтики сближаются с предпочтениями титульного населения, что вступление в НАТО этих стран вовсе не угрожает России. Главное якобы заключалось в освобождении демократической России от имперских амбиций, ибо все ее проблемы-де это объективное следствие советской истории - «преступного» пакта Молотова-Риббентропа и нелегитимного лишения советскими войсками в 1940 г. независимости прибалтийских государств.

Очевидный концептуальный провал российской внешней политики начала 1990-х годов в этом важнейшем регионе, несмотря на отдельные прорывы, сегодня обернулся для России утратой ее почти трехсотлетних позиций на Балтике, членством прибалтийских республик в НАТО и превращением их в наиболее враждебный России «отряд» в европейских международных структурах. В демократической Европе, гордящейся своими стандартами в области прав человека, появился внушительный контингент «неграждан» - лиц без гражданства.

«Демократическая Россия» весьма далека от имперства. Но через 25 лет после вывода российских войск из Прибалтики легионеры СС и их сторонники маршируют по улицам Риги и Таллина, памятники советским солдатам низвергаются при полном попустительстве НАТО и ЕС, русские лишены права получать образование на родном языке, правительства и парламенты прибалтийских государств принимают документы о том, что победа над фашизмом была поражением и оккупацией. Мировое сообщество на все более официальном уровне соучаствует в ревизии интерпретации смысла и истории Второй мировой войны, забыв не только о собственных прежних оценках, но и о собственных прошлых деяниях.

\section{Литература}

Договор между Союзом Советских Социалистических Республик и Соединенными Штатами Америки об ограничении систем противоракетной обороны 26 мая 1972 г. // Сборник действующих договоров, соглашений и конвенций, заключенных СССР с иностранными госу- 
дарствами. М. 1974. Вып. XXVIII. С. 31-35. - URL: armscontrol.ru/start/rus/docs/abm-treaty. htm (дата обращения: 04.08.2019).

Нарочницкая Н.А. Россия в идейных и геополитических проектах мировой истории, конец XIX - XX вв.: В свете религиозно-философских основ истории: диссертация ... доктора исторических наук: 07.00.02, 07.00.03. М. 2002. - 553 с.

Указ Президента Российской Федерации. 0 делегации Российской Федерации на переговоpax с Латвийской Республикой. — URL: docs.cntd.ru/document/901603374 (дата обращения: 04.08.2019).

Постановление Государственного Совета СССР от 6 сентября 1991 г. № ГС-22 «0 признании независимости Латвийской Республики» // Ведомости СНД и ВС СССР. 1991. № 37. — URL: vedomosti.sssr.su/1991/37/\#1091 (дата обращения: 04.08.2019).

Соглашение между Российской Федерацией и Латвийской Республикой о правовом статусе Скрундской радиолокационной станции на период её временного функционирования и демонтажа. — URL: docs.cntd.ru/document/1900468 (дата обращения: 04.08.2019). 